\title{
Research Paper: \\ The Protective Effects of Jamun Seeds and Orange Peels Extracts on Cal- citonin Cells and Parathyroid Glands against Cypermethrin Toxicity
}

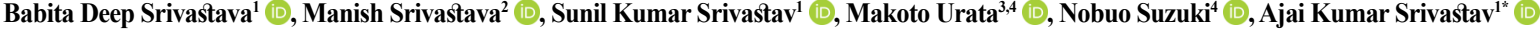

1. Department of Zoology, Faculty of Science, Deen Dayal Upadhyay, Gorakhpur University, Gorakhpur, India.

2. Department of Chemistry, Faculty of Science, Digvijai Nath P.G. College, Gorakhpur, India.

3. Institute of Noto Satoumi Education Research, Noto-cho, Ishikawa, Japan.

4. Noto Marine Laboratory, Institute of Nature and Environmental Technology, Division of Marine Environmental Studies, Kanazawa University, Noto-cho, Ishikawa, Japan.

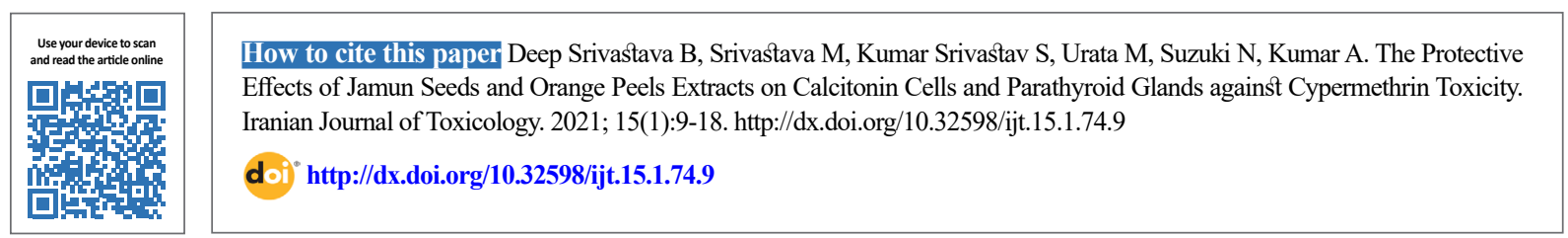

\section{(i) (8)}

Article info:

Received: 02 Jun 2020

Accepted: 31 Oct 2020

Online Published: 01 Jan 2021

* Corresponding author:

Ajai Kumar Srivastav, PhD.

Address: Department of Zoology,

Faculty of Science, Deen Dayal

Upadhyay, Gorakhpur University,

Gorakhpur, India.

E-mail:ajaiksrivastav@hotmail.com

\section{ABSTRACT}

Background: This study aimed to investigate changes in Calcitonin Cells (C cells) and Parathyroid Glands (PTG) induced by cypermethrin exposure in rats and evaluate the protective effects of Jamun Seeds (Syzygium cumini; JSE) and orange peels (Citrus sinensis; OPE) extracts.

Methods: Wistar rats $(\mathrm{N}=120)$ were treated in groups of 20 each as: A. Controls; B. Cypermethrin (CY); C. Cypermethrin and JSE; D. Cypermethrin and OPE; E. OPE; F. JSE. Thyro-parathyroid tissue samples were fixed on days 15 or 30 following each treatment.

Results: Cypermethrin treatment in rats either alone or combined with JSE or OPE caused degranulation of calcitonin cells and mitochondrial enlargement on day 15 of exposure. Nuclear volume of C cells in groups B, C and D remained unchanged. On day 30 , we found increased nuclear volumes, accumulation of secretory granules and degeneration of $\mathrm{C}$ cells. In groups $\mathrm{E}$ and $\mathrm{F}$ no changes in the morphology of C cells were observed. The PTG cells treated with cypermethrin or CY+JSE or CY+OPE over 15 days exhibited hyperchromatic, elongated and increased in volume of the nuclei. The nuclei of PTG cells treated with cypermethrin, $\mathrm{CY}+\mathrm{JSE}$ or $\mathrm{CY}+\mathrm{OPE}$ were hyperchromatic and elongated on day 30 . Degenerate nuclei were detected after cypermethrin treatment, and the nuclear volumes were increased on day 30 . In groups $\mathrm{E}$ and $\mathrm{F}$ there were no changes in PTG cells on days 15 and 30 post treatment.

Conclusion: Cypermethrin provoked alterations in the calcitonin and PTG cells, with microscopic evidence of protection after treatment with JSE and OPE.

Keywords: Cyprmethrin, Calcitonin cells, Parathyroid gland cells, Jamun seeds, Orange peels

\section{Introduction}

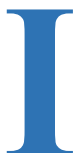

$\mathrm{n}$ recent years, there has been a growing awareness on the increased use of pesticides in everyday life, which pollute our environment and worsen the health of non-target or- ganisms and humans [1-3]. Pyrethroids are the most widely used insecticides as they are highly effective against a wide range of insects, easily biodegradable and least toxic to mammals [4]. Cypermethrin is a broad spectrum synthetic insecticide, which is used to control agricultural and household insects [4]. 
The broad use of cypermethrin leads to its entry into water resources and provokes detrimental effects on humans and other organisms. The adverse effects include neurological, genetic and hematological toxicities, generation of reactive oxygen species, and toxic alterations in the liver, kidneys and reproductive organs [5-9]. Jamun (Syzygium cumini) has antidiabetic, antimalarial, antibacterial, free radical scavenging, anti-ulcer and antifertility properties $[4,10,11]$. Citrus sinensis in orange peels contains hespiridin and possesses antioxidant, antiinflammatory, anti-cancer and antilipedemic activities [12]. Ahmed et al. [13] have reported that orange peels contain naringin and naringenin, which have antimicrobial, antidiabetic and antitoxic activities.

In vertebrates, calcium ions play a vital role in a variety of biological functions, such as cell adhesion, muscle contraction, membrane permeability, neuronal excitability, blood clotting, and in the organism's response to fluctuations in acid-base balance [14]. Calcium is also essential for the initiation of many endocrine events, such as hormone release and responses of their definitive effectors [14]. Several hormones have been reported to control the blood calcium level, including calcitonin, parathyroid hormone and vitamin D [14]. Birnbaum et al. [15] stated that a small amount of hormones is needed for the functioning of endocrine systems and; therefore, endocrine disruption occurs at far lower exposure levels than those usually considered as being toxic. During the last decade, few studies have reported that environmental toxicants have disrupting effects on the endocrine systems in mammals [16-19]. Few studies have correlated serum levels of calcitonin, calcium and phosphate, and changes in the histological structures of calcitonin and parathyroid cells with some toxicants, such as cadmium [20-24], heroin $[25,26]$, mipcin [27], diazinon [28] and chlorpyrifos [29].

\section{Materials and Methods}

\section{Materials and Methods}

In the absence of relevant data from previous studies, we aimed at investigating the changes in calcitonin and parathyroid cells in response to cypermethrin exposure in rats. We also examined the possible protective role of extracts from jamun seeds and orange peels.

Male Wistar rats $(\mathrm{N}=120)$ weighing $115-130 \mathrm{~g}$ were housed in polypropylene cages under natural light. All treatments were started after 2 weeks of acclimatization of the rats to the laboratory condition, and were kept on standard laboratory feed and water ad libitum throughout the experiment. The study was approved by Ethics Committee of DDU Gorakhpur University, Gorakhpur, India. The rats were divided into six groups of 20 each, designated as A, B, C, D, E, and F. The treatments were given daily to the groups at 08:00 a.m. everyday throughout the study as mentioned in Table 1.

Preparations of jamun seeds and orange peels extracts have previously been described by Srivastava et al. [4]. Rats from all groups were sacrificed $24 \mathrm{hr}$ after the last treatment on either the 15th or 30th day of the initiation of the study. Animals were fasted overnight before sacrifice.

Blood biochemical analyses: In each experiment, the rats were lightly anesthetized with ether and blood samples were collected by cardiac puncture, using a $3 \mathrm{ml}$ syringe with a 23 gauge needle. The blood samples thus collected were allowed to clot for 30 minutes at room temperature. The sera were separated by centrifugation at $3000 \mathrm{rpm}$ and kept in a freezer at $-20^{\circ} \mathrm{C}$ until analyzed. The blood analyses determined the electrolytes, using calcium diagnostic kits (Sigma-Aldrich; St. Louis, MS, USA). All determinations were carried out in duplicate test tubes from each serum sample.

Table 1. Details of treatments given to rats

\begin{tabular}{cc}
\hline Group & Treatments \\
\hline A & Control, no treatment given \\
B & Cypermethrin: Rats received a daily dose of cypermethrin $(25 \mathrm{mg} / \mathrm{kg})$. \\
D & $\begin{array}{r}\text { Cypermethrin + orange peels extract: These rats were given daily doses of cypermethrin }(25 \mathrm{mg} / \mathrm{kg}) \text { and orange } \\
\text { peels extract }(200 \mathrm{mg} / \mathrm{kg}) \text { simultaneously. }\end{array}$ \\
E & Orange peels extract: Rats received a daily dose of orange peels extract $(200 \mathrm{mg} / \mathrm{kg})$. \\
F & Jamun seeds extract: Rats received a daily dose of jamun seeds extract $(200 \mathrm{mg} / \mathrm{kg})$. \\
\hline
\end{tabular}


Light microscopy: After sacrificing each rat, one lobe of the thyroid-parathyroid gland was fixed in Glutaraldehyde-Picric Acid (GPA) mixture with the other lobe fixed in Bouin's fluid. The fixed thyroid and parathyroid tissue samples were processed by routine histological paraffin method, sectioned at $6 \mu \mathrm{m}$, and stained with Hematoxylin and Eosin (H\&E) for light microscopic examination. Lead hematoxylin was used as the specific stain for the identification of calcitonin cells in the thyroid. Photomicrographs were taken by Olympus $\mathrm{CH} 20 \mathrm{i}$ microscope equipped with an Olympus E-420 camera.

Electron microscopy: For EM studies, small pieces of thyroid and parathyroid tissue samples were fixed in a mixture of paraformaldehyde and glutaraldehyde for $4 \mathrm{hr}$ at $4^{\circ} \mathrm{C}$, washed with phosphate buffer saline and stored at $4^{\circ} \mathrm{C}$. These tissue samples were processed at Sophisticated Analytical Instrument Facility at All India Institute of Medical Sciences, New Delhi, India.

Measurement of nuclear volume: Nuclear indices (maximal length and width) of the calcitonin and parathyroid cells were measured, using an ocular micrometer, and the nuclear volumes were calculated as follows: volume $=4 / 3$ п $a b 2$, where ' $a$ ' was the major semiaxis and ' $b$ ' was the minor semiaxis. In the glands with degenerate nuclei only the indices of intact nuclei were measured.

Statistical analyses: Data were presented as the Means \pm SE for five specimens. Student t-test was used to determine the statistical significance level at $\mathrm{P}<0.05$. Each treated group was compared to its specific treatment time with the control group. Analysis of Variance (ANOVA) was used to determine the significant differences among various treatment groups.

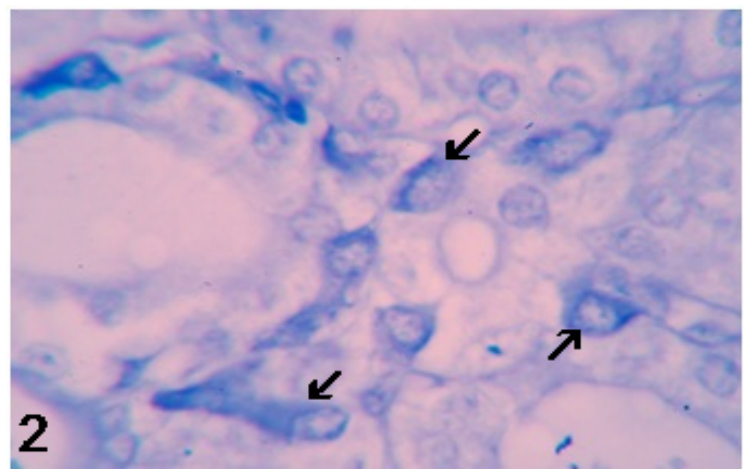

Figure 2. Typical calcitonin cells (arrows) in control rats

Lead hematoxylin stained. Mag. X 500.

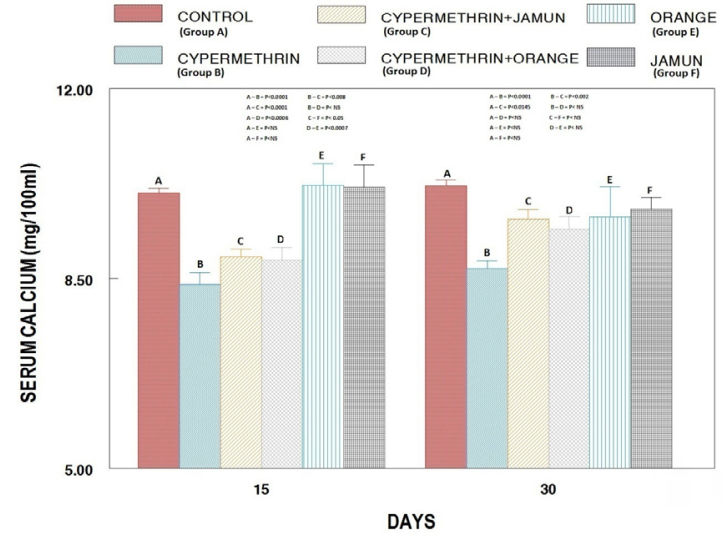

Figure 1. The serum calcium levels of rats after various treatments

All values indicate Mean $\pm S E$ of five specimens.

\section{Results}

Serum parameters: The rats in group B, treated with cypermethrin, exhibit a decrease in serum calcium levels after 15 or 30 days of exposure $(\mathrm{P}<0.0001$; Figure 1$)$. In group $\mathrm{C}$ (cypermethrin \& JSE), the serum calcium level decreased on days $15(\mathrm{P}<0.0001)$ and $30(\mathrm{P}<0.014)$, as compared to group A. However, the calcium levels in group $\mathrm{C}$ slightly increased on day 30 as compared to that on day 15 . In group D (cypermethrin \& OPE), the serum calcium level decreased on day 15 as compared to that in group $\mathrm{A}(\mathrm{P}<0.0006)$. However, on day 30 , the calcium level increased insignificantly as compared to that in the controls. The calcium levels in group $\mathrm{C}$ increased on days $15(\mathrm{P}<0.008)$ and $30(\mathrm{P}<0.002)$ as compared to that in group $\mathrm{B}$. Moreover, the calcium level changes in group D were not significant on days 15 and 30 as compared to that in group B. In group E (OPE) and group F (JSE), there were no changes in serum calcium levels on days 15 and 30 of treatment. The statistical analysis ANOVA demonstrated that the treatment caused sig-

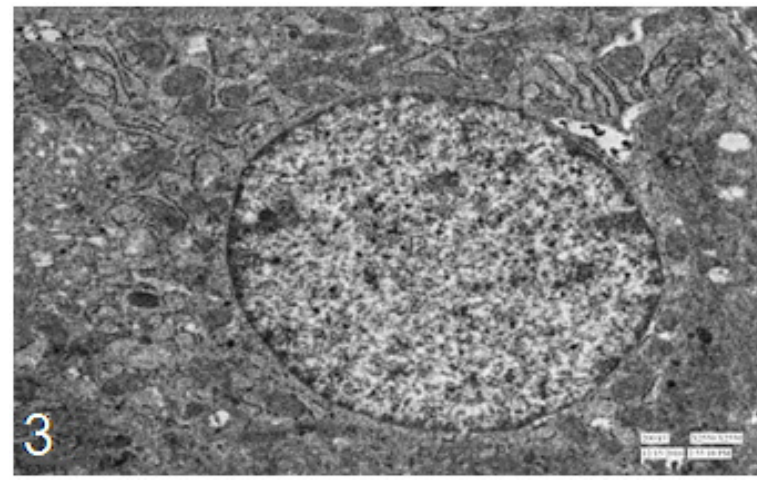

Figure 3. Typical electron micrograph of calcitonin cells in control rats 


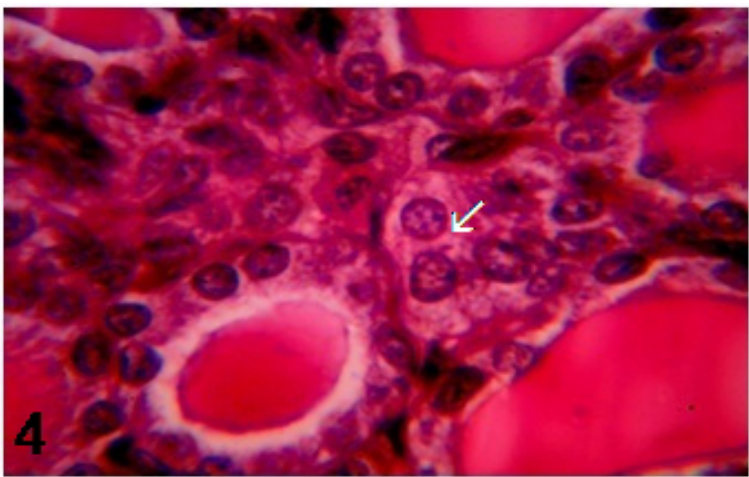

Figure 4. Typical lightly stained calcitonin cells (arrow) in the thyroid gland of control rats

Hematoxylin-eosin stained. Mag. X 500.

nificant changes in the serum calcium levels (day-15: $\mathrm{F}=12.004, \mathrm{P}<0.0001$; day-30: $-\mathrm{F}=2.658, \mathrm{P}<0.041$ ).

\section{Microscopic findings}

\section{Calcitonin cells}

Control: The calcitonin cells ( $\mathrm{C}$ cell) in group A rats (controls) were present either singly or in groups of 2-8 within the basement membrane of the thyroid follicles. The $\mathrm{C}$ cells were parafollicular, intrafollicular or epifollicular in position. These cells were oval or pear-shaped with ovoid nuclei (Figures $2 \& 3$ ), which were larger than those of follicular cells (Figure 2). Few $\mathrm{C}$ cells were noted with small nuclei and elongated cytoplasmic processes. In H\&E preparations, $\mathrm{C}$ cells could be differentiated from the follicular cells by being lightly stained (Figure 4). These cells were observed as blue-black in contrast to the follicular cells in response to staining with lead hematoxylin (Figure 2).

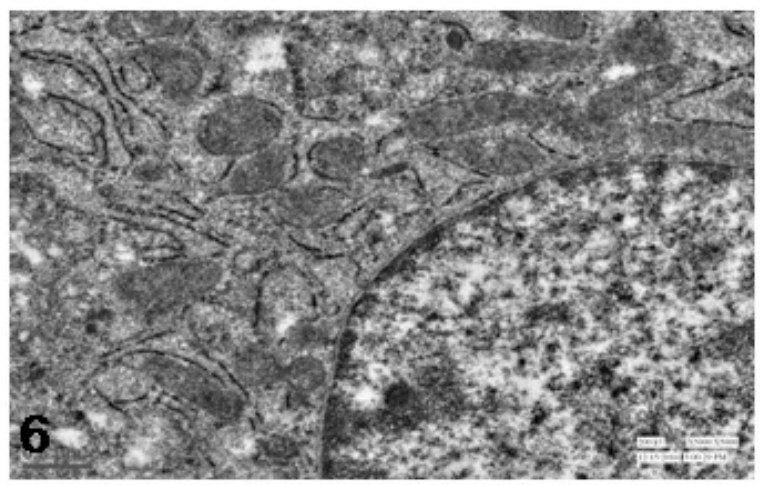

Figure 6. Typical electron micrograph of calcitonin cells in 15-day cypermethrin exposed rats, showing mitochondrial swelling and prominent rough endoplasmic reticula.

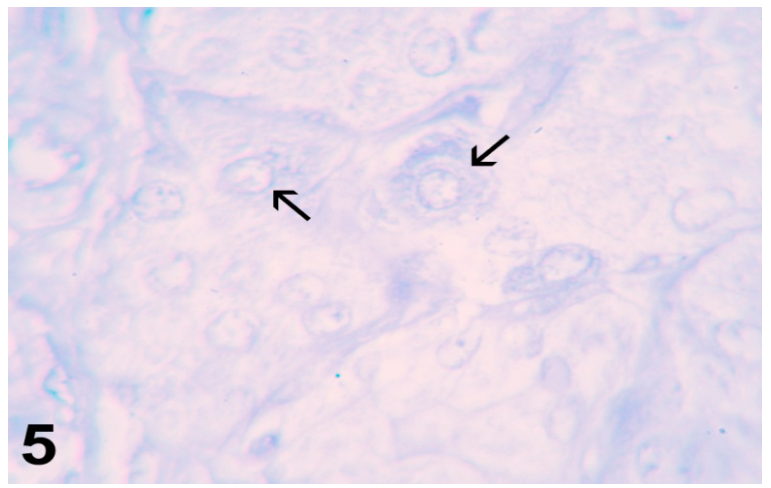

Figure 5. Typical calcitonin cells in 15-day cypermethrin treated rats, showing degranulation (arrows)

Lead hematoxylin stained. Mag. X 500.

Effect of cypermethrin: Cypermethrin treatment in rats either alone (group B) or in combination with jamun seeds extract (group C) or orange peels extract (group D) caused degranulation of the calcitonin cells on day 15 (Figure 5 ) and enlargement of the mitochondria (Figure 6). The nuclear volume of $\mathrm{C}$ cells in groups $\mathrm{B}, \mathrm{C}$ and $\mathrm{D}$ remained unchanged (Figure 7). In these groups, the accumulation of secretory granules in C cells was observed on day 30 of treatment (Figures $8 \& 9$ ). Complete exhaustion of few $\mathrm{C}$ cells were also noticed in rats after 30 day of exposure to cypermethrin (group B) or cypermethrin + JSE (group C) or cypermethrin + OPE (group D) (Figures 10 and 11).

Increased nuclear volumes of $\mathrm{C}$ cells in rats treated with cypermethrin (group B) or cypermethrin + JSE (group C) or cypermethrin + OPE (group D) were detected on day 30 (Figure 7) as compared to that in the controls (group A). In groups $\mathrm{E}$ and $\mathrm{F}$, no changes in the morphological structures and nuclear volumes of $\mathrm{C}$ cells

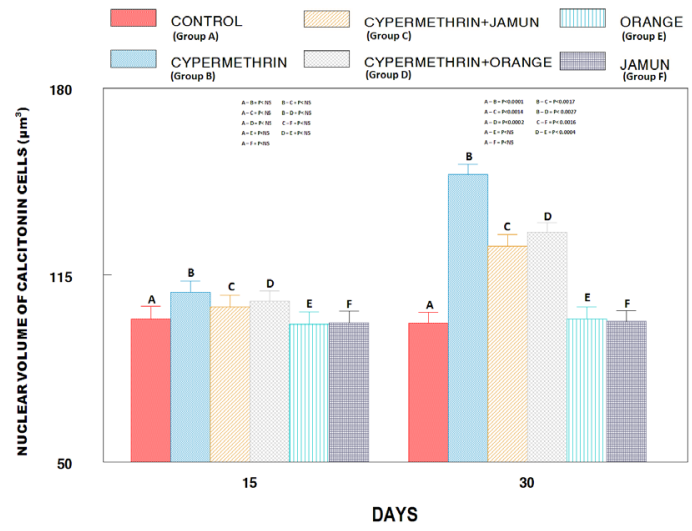

Figure 7. Nuclear volume of calcitonin cells $(\mu \mathrm{m} 3)$ of rats after various treatments

All values indicate Mean \pm SE of five specimens. 


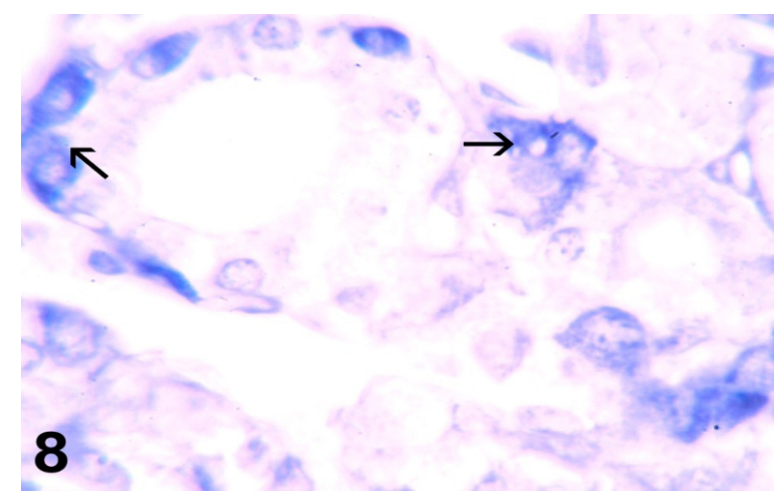

Figure 8. Accumulation of secretory granules (arrows) in calcitonin cells of 30-day cypermethrin exposed rats

Lead hematoxylin stained. Mag. X 500.

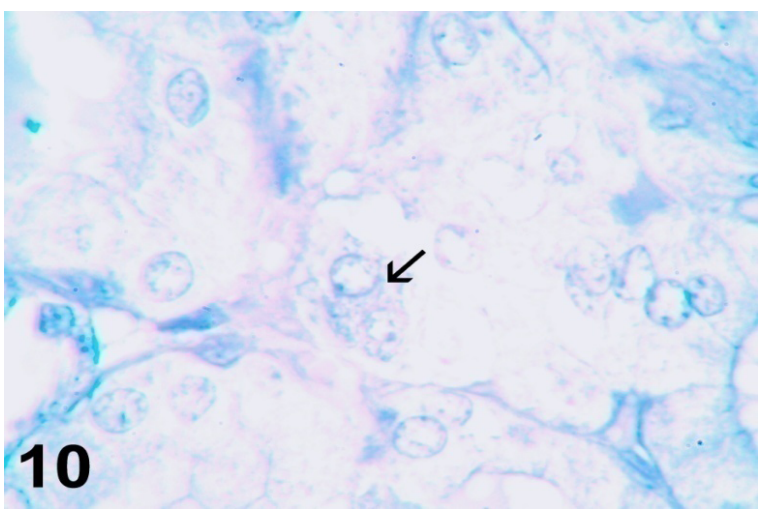

Figure 10. Completely exhausted calcitonin cells (arrow) in 30-day cypermethrin exposed rats

Lead hematoxylin stained. Mag. X 500.

were observed throughout the experiments. The nuclear volumes of $\mathrm{C}$ cells were not significantly different from those in the controls on day $15(\mathrm{~F}=1.216, \mathrm{P}<0.4272)$ but were significantly different on day $30(\mathrm{~F}=32.377$, $\mathrm{P}<0.0001$ ) based on ANOVA analysis.

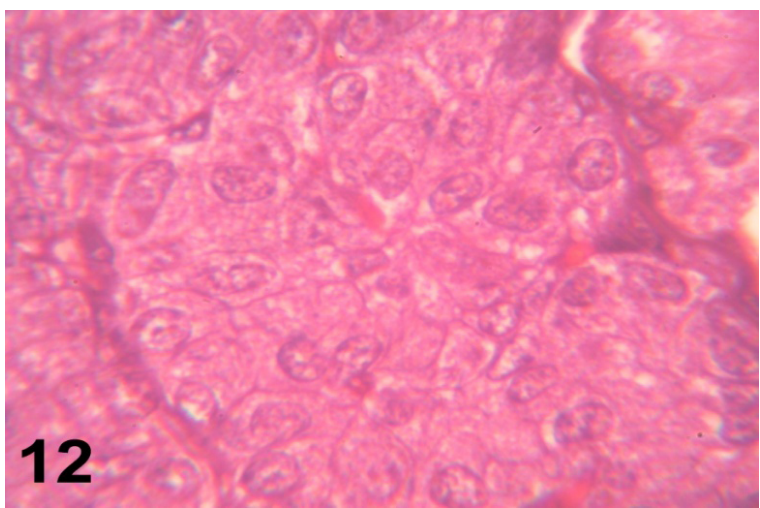

Figure 12. Typical parathyroid gland in control rats

Hematoxylin-eosin stained. Mag. X 500.

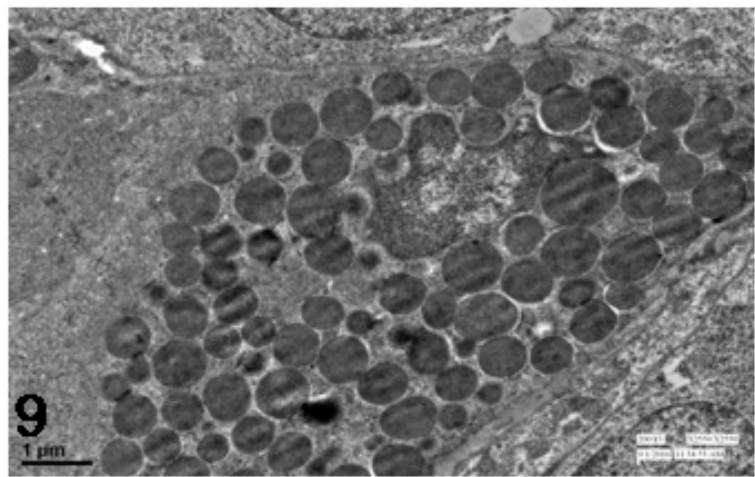

Figure 9. Typical electron micrograph of 30-day cypermethrin treated rats, exhibiting accumulation of secretory granules

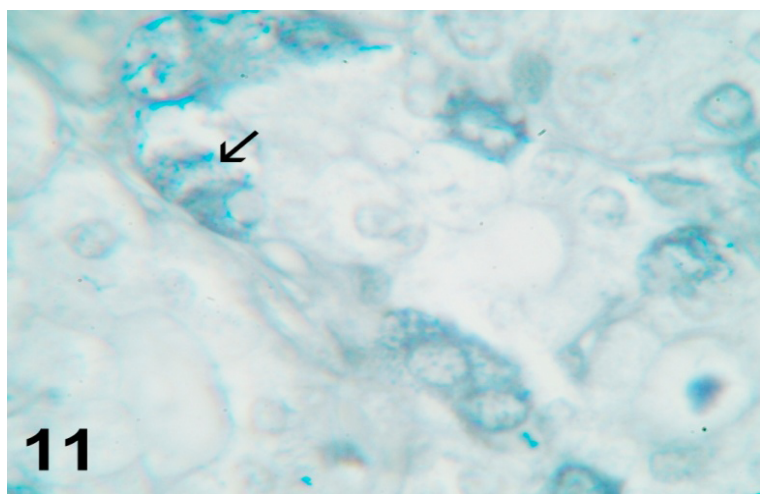

Figure 11. Typical degenerated calcitonin cell (arrow) in 30day cypermethrin treated rats

Lead hematoxylin stained. Mag. X 500.

Parathyroid glands

Controls: In group A rats (controls), the parathyroid glands were composed of densely packed chief cells arranged in cords (Figure 12). Chief cells were seen with indistinct cellular boundary, scanty cytoplasm and large, centrally located, ovoid nuclei (Figures $12 \& 13$ ). There



Figure 13. Typical electron micrograph of parenchymal cells of parathyroid gland in control rats 


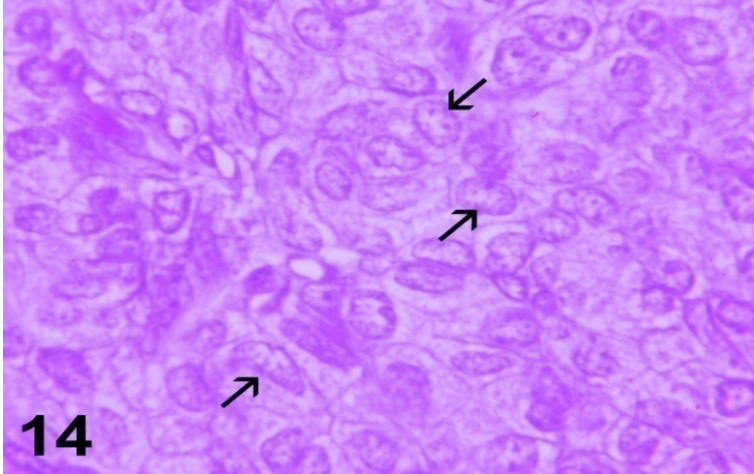

Figure 14. Typical parathyroid glands in 15-day cypermethrin treated rats, showing hyperchromatic and elongated nuclei (arrows)

Hematoxylin-eosin stained. Mag. X 500.

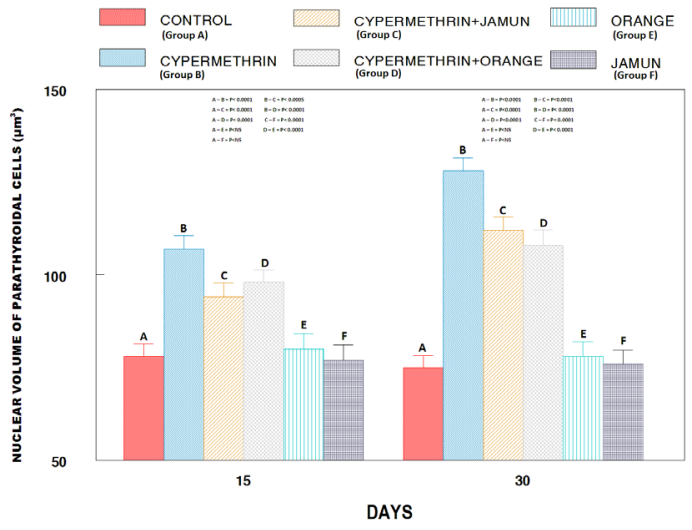

Figure 16. Nuclear volume of parathyroidal cells $(\mu \mathrm{m} 3)$ of rats after various treatments

All values indicate Mean $\pm S E$ of five specimens.

was a framework of reticular fibers with many sinusoidal capillaries among the chief cells.

Effect of cypermethrin: The parathyroid glands from the rats treated with cypermethrin, cypermethrin + JSE or cypermethrin + OPE (groups B, C \& D) exhibit hyperchromatic nuclei (Figures $14 \& 15$ ). Nuclear elongation

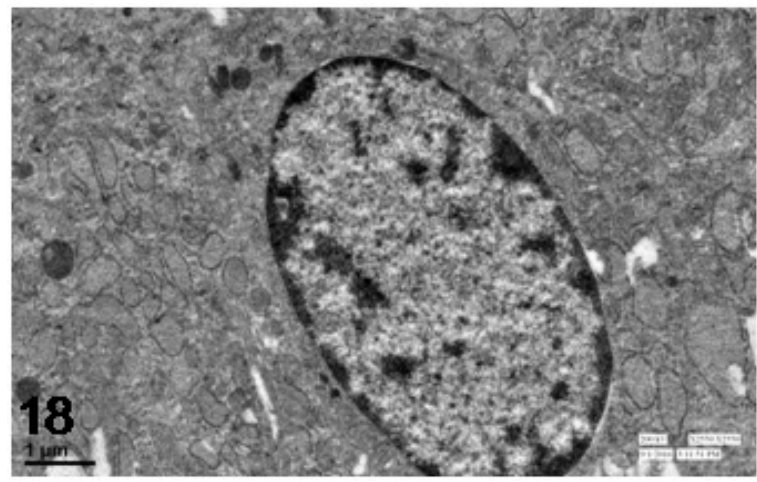

Figure 18. Typical electron micrograph of parathyroidal cells in 30-day cypermethrin treated rats, showing elongated nuclei



Figure 15. Typical electron micrograph of parathyroidal cell in 15-day cypermethrin exposed rats, showing nuclear elongation

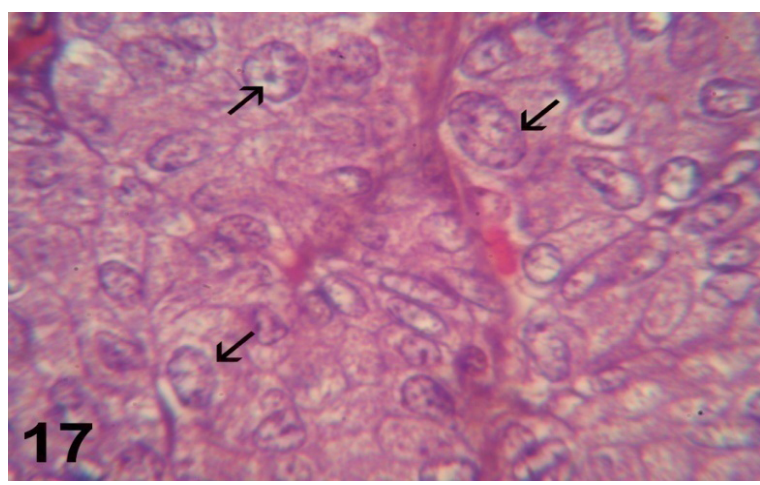

Figure 17. Typical hyperchromatic and elongated nuclei (arrows) in the parathyroid gland of 30-day cypermethrin exposed rats

Hematoxylin-eosin stained. Mag. X 500.

(Figures $14 \& 15$ ) and increased volume of parathyroid cells (Figure 16) were also recorded on day 15 in response to treatment with cypermethrin (group B), cypermethrin + JSE (group C) or cypermethrin + OPE (group D). On day 15 , there were no histological alterations in the parathyroid glands of rats treated with orange peels (group E) and

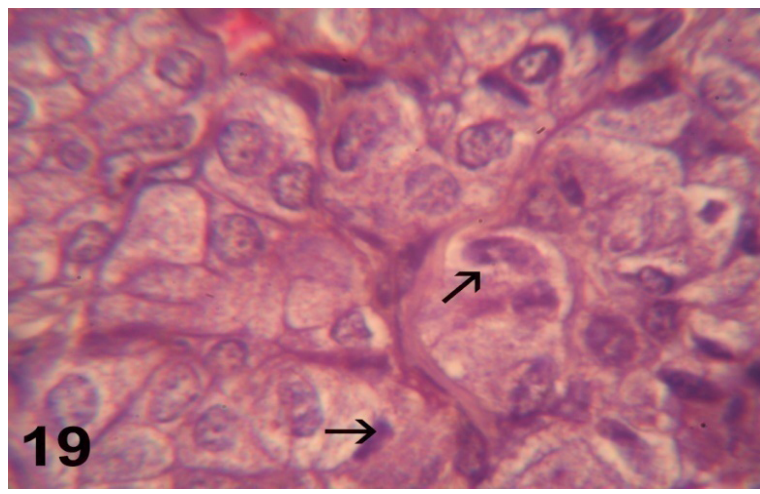

Figure 19. Typical degenerated nuclei (arrows) in the parathyroid gland of 30-day cypermethrin treated rats

Hematoxylin-eosin stained. Mag. X 500. 


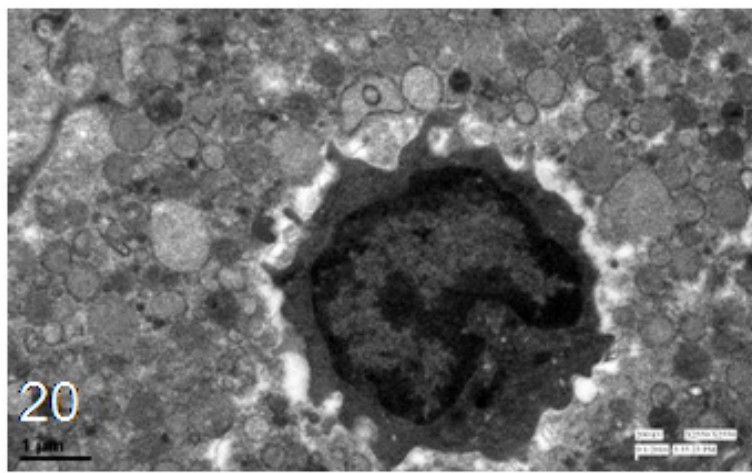

Figure 20. Typical electron micrograph of parathyroidal cells in 30-day cypermethrin exposed rats, exhibiting degenerated nuclei

jamun seeds extracts (group F). The ANOVA statistical analyses indicated that the treatments caused significant differences in the nuclear volumes ( $\mathrm{F}=193.03, \mathrm{P}<0.0001)$.

Nuclear changes: The nuclei of parathyroidal cells after 30 days of treatment with cypermethrin (group B) became more hyperchromatic (Figure 17) and elongated (Figures $17 \& 18$ ) than those in the control group. Also, increases in nuclear volumes were observed (Figure 16). Degenerate nuclei were visible in group B in response to cypermethrin treatment on day 30 (Figures $19 \& 20$ ). The parathyroid cells of the rats treated with cypermethrin and jamun seeds extract (group C) and cypermethrin and orange peel extract (group D) exhibited hyperchromatic and elongated nuclei on day 30 (Figure 21). The nuclear volumes increased after these treatments on day 30 (Figure 16). In groups $\mathrm{E}$ and $\mathrm{F}$, there were no structural changes in the parathyroid cells compared to those in the controls (group A). The changes in the nuclear volumes were significantly different in response to the treatments given to groups $\mathrm{E}$ and $\mathrm{F}$ compared to that seen in the controls $(\mathrm{F}=188.62 ; \mathrm{P}<0.0001)$ based on ANOVA analysis.

\section{Discussion}

The regulation of blood calcium level is believed to be governed by parathyroid glands, which act at three major body organs: bones, kidneys and intestine. In the present study, parathyroid glands hyperactivity, which was evident by hyperchromatic nuclei and increased nuclear volumes, was observed in rats treated with cypermethrin. Hyperactivity of parathyroid glands has also been reported in rats after exposure to chlorpyrifos [29] and in frogs after cadmium treatment [1]. The hyperactivity of parathyroid gland can be attributed to the hypocalcemia recorded in the present study after cypermethrin treatment.

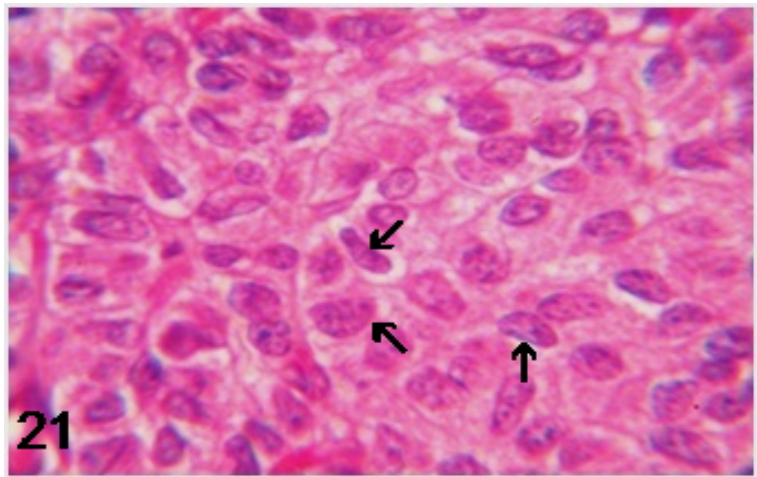

Figure 21. Typical hyperchromatic and elongated nuclei (arrows) in the parathyroid gland of 30-day cypermethrin+orange peel extract exposed rats

Hematoxylin-eosin stained. Mag. X 500.

The calcium levels in group $C$ increased on days 15 and 30 as compared to that in group B. This indicates that jamun seed extract is effective in recovering the calcium levels which was decreased by treatment with cypermethrin. Moreover, the calcium level changes in group D was not significant on days 15 and 30 as compared to that in group B. This indicates that orange peel extract is not effective in restoring the decline in calcium levels caused by cypermethrin.

Compston, et al. have reported that exposure to organophosphates reduced bone formation [30]. Reduced mineral density in bones has also been reported after DDT exposure [31]. Further, Koyama and Itazawa [32] and Muramoto [33] have provided evidence of bone demineralization in cadmium-exposed carps. They have interpreted this event as a mechanism to restore plasma calcium levels in the treated animals. The parathyroid hyperactivity in the rats treated with cypermethrin can be interpreted as the mechanism to maintain normal blood calcium levels through demineralization of bones secondary to the action of parathyroid hormone.

In this study, cypermethrin treated rats exhibited decreased staining of calcitonin cells on day 15 of treatment. Also, the accumulation of secretory granules and increased nuclear volumes of $\mathrm{C}$ cells were recorded on day 30 of cypermethrin treatment. In a previous study, no changes have been reported in calcitonin cells of rats treated with diazinon [28]. In the current study, the observed degranulation of $\mathrm{C}$ cells in the rats exposed to cypermethrin is consistent with the findings of earlier studies that have reported reduced staining and weak immune-cytochemical responses of calcitonin cells after being treated with various toxicants, such as chlorpyrifos [29], heroin [34] and cadmium [21, 24]. 
The findings of the current study are also supported by the observations of Srivastav, et al. [1] who have reported decreased staining of the ultimobranchial gland (secreting calcitonin) in Indian skipper frogs after exposure to cadmium. Increased circulating calcitonin level has also been recorded in rats exposed to cadmium by another study [22]. This hormone is known to protect the boney skeleton in mammals [35]. In this context, the increased release of granules from $\mathrm{C}$ cells in response to cypermethrin treatment in rats could be attributed to the hyperactivity of parathyroid glands. The degeneration of $\mathrm{C}$ cells at later stages of exposure to cypermethrin in rats may possibly be due to excessive degranulation or exhaustion of the cells after prolonged hyperactivity.

Limitation of the Study: In this study, we only performed light and electron microscopic examinations. It would have been more informative if alterations in the circulating levels of calcitonin and parathyroid hormones would have been measured by biochemical tests.

Recommendation for Future Research: The current study did not investigate some areas which need to be explored in future studies. We recommend the determination of the calcium levels and circulating levels of calcitonin and parathyroid hormones in the blood samples of rats after treatment with cypermethrin, jamun seed and orange peel extracts.

\section{Conclusions}

Based on our findings, it can be concluded that cypermethrin provokes alterations in the calcitonin cells and parathyroid glands leading to their excessive hormone release. These endocrine glands regulate blood calcium level, which is vital for the physiological functions in many organisms. Hence, structural changes in these endocrine glands could cause serious threat to the organism's physiological functions. It may also be concluded that the extract from jamun seeds and orange peels can protect the endocrine glands against the cypermethrin toxicity.

\section{Ethical Considerations}

\section{Compliance with ethical guidelines}

This study was conducted by fully observing the ethical guidelines of the Laboratory Animal Ethics Committee of the DDU Gorakhpur University, Gorakhpur, India.

\section{Funding}

The corresponding author would like to thank to the University's Grants Commission, New Delhi, India, for providing financial assistance in support of this study. This work was also supported in part by a cooperative research agreement with the Institute of Nature and Environmental Technology, Kanazawa University, Kanazawa, Japan (Agreement \#: 20007).

\section{Author's contributions}

Conceptualization and methodology: Ajai Kumar Srivastav, Nobuo Suzuki and Makoto Urata; Experiments: Babita Deep Srivastava, Manish Srivastava and Sunil Kumar Srivastav; Writing the manuscript: Babita Deep Srivastava, Manish Srivastava; Review \& editing of the final draft: Ajai Kumar Srivastav, Nobuo Suzuki, Makoto Urata; Funding acquisition, resources: Ajai Kumar Srivastav, Nobuo Suzuki; Supervision: Ajai Kumar Srivastav, Sunil Kumar Srivastav.

\section{Conflict of interest}

The authors declared no conflict of interests.

\section{Acknowledgements}

The authors are thankful to Sophisticated Analytical Instrument Facility, All India Institute of Medical Sciences, New Delhi, India, for processing the tissue samples prior to the electron microscopic examinations.

\section{Refernces}

[1] Srivastav AK, Srivastava S, Srivastav SK, Faggio C, Sekiguchi T, Suzuki N. Response of ultimobranchial and parathyroid glands of the indian skipper frog, euphlyctis cyanophlyctis to cadmium toxicity. Iran J Toxicol. 2019; 13(3):39-44. http://ijt. arakmu.ac.ir/article-1-748-en.html

[2] Mahat S, Jha CB, Shrestha S, Koirala S. Effect of vitamin E on cypermethrin induced toxicity in cerebral cortex of Wistar albino rats: A histological study. J Karnali Acad Health Sci. 2020;3(1):1-10. [DOI:10.3126/jkahs.v3i1.28457]

[3] Majumder R, Kaviraj A. Acute toxicity of cypermethrin to freshwater fish Oreochromis niloticus: Influence of aquatic weed and turbidity of water. National Academy Science Letters, 2020. [DOI:10.1007/s40009-020-00944-w]

[4] Srivastava BD, Srivastava M, Srivastav SK, Suzuki N, Srivastav AK. Cypermethrin-induced liver histopathology in rat: Protective role of jamun seed and orange peel extracts. Iran J Toxicol. 2018; 12(4):25-30. http://ijt.arakmu.ac.ir/article1-689-en.html

[5] Mezni A, Mhadhbi L, Khazri A, Sellami B, Dellahi M, Mahmoudi E, et al. The protective effect of Hibiscus sabdariffa calyxes extract against cypermethrin induced oxidative 
stress in mice. Pesticide Biochem Physiol. 2020; 165:104463. [DOI:10.1016/j.pestbp.2019.09.007] [PMID]

[6] Das T, Ghosh R, Paramanik A, Pradhan A, Dey SK, Roy T, et al. Dose-dependent hematological, hepatic and gonadal toxicity of cypermethrin in Wistar rats. Toxicol Forensic Med Open J. 2017; 2(2):74-83. [DOI:10.17140/TFMOJ-2-122]

[7] Yousef DM, El-Fatah SSA, Hegazy AA. Protective effect of ginger extract against alterations of rat thyroid structure induced by cypermethrin administration. J Exp Med Biol. 2019; 1(1):19-25. https:/ / www.pulsus.com/abstract/protective-effect-of-ginger-extract-against-alterations-of-rat-thyroid-structure-induced-by-cypermethrin-administration-5031.html

[8] Abdul-Hamid M, Moustafa N, Mowafy L. Cypermethrininduced histopathological, ultrastructural and biochemical changes in liver of albino rats: The protctive role of propolis and curcumin. Beni-Suef Univ. J Basic Appl Sci. 2017; 6:160-173. [DOI:10.1016/j.bjbas.2017.03.002]

[9] Simon U, David O, Peter R, Joseph R, Ijeoma C, Celestine N. Pathological effects of cypermethrin on the testes and accessory sexual glands of Yankasa rams. Arch Pathol Clin Res. $2018 ; 2: 6-12$

[10] Srivastava BD, SrivastavAjai K. Hepatoprotective effects of extracts of Syzygium cumini seeds and Citrus sinensis peels against microcystin LR-induced toxicity in rat. Intern J Zool Invest. 2017; 3:95-105.

[11] Chagas VT, Coelho RMRS, Gaspar RS, da Silva SA, Mastrogiovanni M, de Jesus Mendonça C, et al. Protective effects of a polyphenol-rich extract from Syzygium cumini (L.) skeels leaf on oxidative stress-induced diabetic rats. Oxid Med Cell Longev. 2018; 2018:5386079. [DOI:10.1155/2018/5386079] [PMID] [PMCID]

[12] Bashandy SAE, Ahmad-Farid OAH, Omara EA, et al. Protective effects of Citrus reticulata peel extract against potassium dichromate-induced reproductive toxicity in rats. Asian Pacific J Reprod. 2019; 8(6):267-75. [DOI:10.4103/23050500.270104]

[13] Ahmed OM, Fahim HI, Ahmed HY, Al-Muzafar HM, Ahmed RR, Amin KA, et al. The preventive effects and the mechanisms of action of navel orange peel hydroethanolic extract, naringin, and naringenin in N-acetyl-p-aminophenolinduced liver injury in Wistar rats. Oxid Med Cell Longev. 2019; 2019:2745352. [DOI:10.1155/2019/2745352] [PMID] [PMCID]

[14] Srivastav Ajai K, Das VK, Srivastav SK, et al. Amphibian calcium regulation: Physiological aspects. Zool Polon. 2000; 45:9-36. http://yadda.icm.edu.pl/yadda/element/bwmeta1.element. agro-article-81520ed4-51da-4aba-8760-3acf53d1d51b

[15] Birnbaum LS. Endocrine-disrupting chemicals in drinking water: Risks to human health and the environment [Internet]. 2010. Available from: https://www.hsdl. org/?view\&did=742814.

[16] Pilat-Marcinkiewicz B, Brzoska MM, Sawicki B, Moniuszko-Jakoniuk J. Structure and function of thyroid follicular cells in female rats chronically exposed to cadmium. Bull Vet Inst Pulawy. 2003, 47(1):157-63.

[17] Jun K, Ryoichi K, Hideo S. Influences of polyaromatic hydrocarbons and heavy metals on the thyroid carcinoma cell line. J Health Sci. 2005; 51(2):202-6. [DOI:10.1248/jhs.51.202]
[18] Yousif AS, Ahmed AA. Effects of cadmium (Cd) and lead $(\mathrm{Pb})$ on the structure and function of thyroid gland. African J Sci Tech. 2009; 3:78-85. https://academicjournals.org/journal/AJEST/article-abstract/15FEF2511844

[19] Tebourbi O, Hallenge D, Yacoubi MT, Sakly M, Ben Rhouma K. Subacute toxicity of p, p'-DDT on rat thyroid: Hormonal and histopathological changes. Environ Toxicol Pharmacol. 2010; 29(3):271-9. [DOI:10.1016/j.etap.2010.03.002] [PMID]

[20] Pilat-Marcinkiewicz B, Sawicki B, Brzoska M, Zabel M. Preliminary immune-histochemical study of $C$ cells of the thyroid and endocrine cells of parathyroid glands in rats after prolonged exposure to cadmium. Folia Histochem Cytobiol. 2001; 39(2):191-2. [PMID]

[21] Pilat-Marcinkiewicz B, Brzoska M, Moniuszko-Jakoniuk J. Thyroid and parathyroid function and structure in male rats chronically exposed to cadmium. Polish J Environ Stud. 2008; 17(1):113-20. http://www.pjoes.com/Thyroid-and-Parathyroid-Function-and-Structure-in-Male-Rats-Chronically-Exposed-to, $88086,0,2 . \mathrm{html}$

[22] Brzoska M, Moniuszko-Jakoniuk J. Effect of low-level lifetime exposure to cadmium on calcitropic hormones in aged female rats. Arch Toxicol. 2005; 79(11):636-46. [DOI:10.1007/ s00204-005-0680-6] [PMID]

[23] Schutte R, Nawrot TS, Richart T, Thijs L, Vanderschueren D, Kuznetsova T, et al. Bone resorption and environmental exposure to cadmium in women: A population study. Environ Hlth Perspect. 2008; 116(6):777-83. [DOI:10.1289/ehp.11167] [PMID] [PMCID]

[24] Tripathi S, Srivastav AK. Alterations in the serum electrolytes, calcitonin cells and parathyroid gland of Wistar rat in response to administration of cadmium. Proc. Intern. Con. Environ. Pollution and Remediation. Ottawa, Ontario, Canada, 17-19 August, Paper No. 12, 2011.

[25] Tagliaro F, Dorizzi R, Lafisca S, Maschio S, Marigo M. Calcitonin serum level in heroin addicts: Effects of methadone and clonidine detoxication treatments. Drug Alcohol Depend. 1985; 16(2):181-3. [DOI:10.1016/0376-8716(85)90116-4]

[26] Barai SR, Suryawanshi SA, Pandey AK. Responses of parathyroid gland, $\mathrm{C}$ cells, and plasma calcium and inorganic phosphate levels in rat to sub-lethal heroin administration. J Environ Biol. 2009; 30(5 Suppl):917-22. [PMID]

[27] Rangoonwala SP, Suryawanshi SA, Pandey AK. Responses of serum calcium and inorganic phosphate levels as well as parathyroid gland and calcitonin producing C cells of Rattus norvegicus to mipcin administration. J Environ Biol. 2007; 28(2):475-81. [PMID]

[28] Rangoonwala SP, Kazim M, Pandey AK. Effects of diazinin on serum calcium and inorganic phosphate levels as well as ultrastructures of parathyroid and calcitonin cells of Rattus norvegicus. J Environ Biol. 2005; 26(2):217-21. [PMID]

[29] Tripathi S, SuzukiN, SrivastavAjai K. Response of serum minerals (calcium, phosphate and magnesium) and endocrine glands (calcitonin cells and parathyroid gland) of Wistar rat after chlorpyrifos administration. Micros Res Tech. 2013; 76(7):673-8. [DOI:10.1002/jemt.22217] [PMID]

[30] CompstonJE, VediS, Stephen AB, Bord S, Lyons AR, Hodges SJ, et al. Reduced bone formation after exposure to organophosphates. Lancet. 1999; 354(9192):1791-2. [DOI:10.1016/ S0140-6736(99)04466-9] 
[31] Beard J, Marshall S, Jong K, Newton R, Triplett-McBride T, Humphries B, et al. 1,1,1-trichloro-2,2-bis(p-chlorophenyl)-ethane (DDT) and reduced bone mineral density. Arch Environ Health. 2000; 55(3):177-80. [DOI:10.1080/00039890009603403] [PMID]

[32] Koyama J, Itazawa, Y. Effects of oral administration of cadmium on fish. I. Analytical results of the blood and bones. Bull Jap Soc Sci Fish. 1977; 43:523-6. [DOI:10.2331/suisan.43.523]

[33] Muramoto S. Vertebral column damage and decrease of calcium concentrations in fish exposed experimentally to cadmium. Environ Poll. (Ser. A). 1981; 24(2):125-33. [DOI:10.1016/0143-1471(81)90074-X]

[34] Li YX, Liang WM. Effects of heroin dependence on rat's calcitonin positive cells in thyroid gland and serum FT3, FT4, TSH. Acta Anat Sinica. 2010; 41(1):100-3. http:/ / wprim. whocc.org.cn/admin/article/articleDetail?WPRIMID $=40434$ $0 \&$ articleId $=404340$

[35] Miller S. Calcitonin- Gaurdian of the mammalian skeleton or is it just a fish story? Endocrinology. 2006; 147(9):4007-9. [DOI:10.1210/en.2006-0599] [PMID] 